удК 347

DOI https://doi.org/10.32837/apdp.v0i85.1867

Ю. П. Пацурківський

\title{
ОКРЕМІ МЕТОДОЛОГІЧНІ ПРОБЛЕМИ РОЗУМІННЯ ПРИРОДИ ВЛАСНОСТІ ТА ПРАВА ВЛАСНОСТІ
}

Постановка проблеми. Аналіз розвитку інституту власності та права власності як речового права дає підстави припустити, що власність пережила період свого абсолютного характеру, нині очевидною є тенденція до ї̈ обмеження. Суб’єкти права власності вже зазнають і будуть надалі терпіти нові обмеження з метою задоволення суспільних інтересів. Зауважу, що саме право власності визначило як розвиток економіки, так і розвиток європейської цивілізації загалом. Цей процес характеризується поступовим обмеженням правомочностей власника та соціалізацією права власності.

Саме тому необхідно досліджувати питання про те, які межі суб'єктивного права власності є допустимими, як встановити та дотриматися балансу інтересів суспільства та окремого суб'єкта права власності чи іншого речового права. Сьогодення дає достатні підстави для висновку про те, що перехід від парадигми абсолютного права власності до парадигми обмеженого права власності вже фактично відбувся. Все це зумовлює актуальність дослідження вже згаданих і суміжних із ними методологічних проблем сучасного розуміння природи власності, права власності та їх реалізації.

Аналіз останніх досліджень і публікацій. Питання методології власності та права власності є важливим та актуальним. Зокрема, власність є фундаментом економіки держави, а також забезпечує існування і розвиток суспільства загалом. Проблеми методології речового права, реалізації власності та права власності, захисту суб'єктивних прав власника, встановлення балансу інтересів між різними суб'єктами в нових економічних реаліях досліджують Н. Кузнєцова, О. Дзера, Р. Майданник, Е. Харитонов, С. Погрібний, О. Яворська, А. Яковлєв та інші.

Метою статті є дослідження сучасних методологічних проблем речового права: сучасної природи власності та права власності, приватних та публічних інтересів і питань їх поділу та взаємодії, проблем визначення та встановлення меж і обмежень права власності, дослідження основних тенденцій розвитку правового регулювання відносин власності в контексті сучасних тенденцій. Мета дослідження була конкретизована в завданнях, які я спробую розв'язати в дослідженні.

Виклад основного матеріалу дослідження. В науці цивільного права триває дискусія про методологічні основи власності і права власності. Вона пов'язана з втіленням у сферу приватного права класичної концепції поділу права на публічне та приватне. Актуальність цієї дискусії зумовлена відсутністю чіткого розмежування між приватним правом і публічним правом.

Слід підкреслити теоретичну можливість взаємопроникнення однієї сфери з властивими їй юридичними методами в іншу. При цьому слід брати до уваги таке твердження: «Перехід від приватноправових засад до публічно-правових не завжди

(C) Ю. П. Пацурківський, 2020 
спричиняє перехід до вищих форм людського спілкування» [8, с. 11]. В цьому випадку суспільні відносини регулюються виключно з волі держави з метою захисту публічних інтересів. Щодо захисту приватних інтересів, то необхідним є встановлення іншого типу правового регулювання, коли державна влада надає можливості регулювання невеликим центрам - самостійним соціальним одиницям, союзам або окремим суб'єктам права. Тобто, йдеться про свого роду децентралізацію.

Одним із важливих складників проблеми, на мою думку, є те, що нині немає однозначного розуміння публічного права і приватного права. Існує декілька підходів до визначення критерію поділу права на публічне та приватне, які можуть бути об’єднані в дві великі групи: матеріальні і формальні.

В контексті досліджуваних проблем заслуговує на увагу теорія інтересу. Зміст цієї теорії визначається твердженням, що право, яке охороняє інтереси держави, публічне, інтереси приватної особи, - приватне. Критерієм розмежування приватного і публічного права є природа інтересів, які забезпечуються цими правовими підсистемами. Ця теоретична конструкція має певні вади. Вона не дає відповіді на питання, що є межею для сфери публічного і приватного інтересу. Ця обставина робить їі застосування проблематичним. На мою думку, ці категорії парні, і працюють вони тільки у взаємодії.

Приватний і суспільний інтереси переплетені в праві так, що їх не можливо чітко розділити. Так, норми, які регулюють відносини власності, належать до приватного права, але абсолютно очевидно, що їх метою є не тільки приватні, а й суспільні інтереси. Приватне право забезпечує реалізацію інтересів осіб-власників. Публічне право - це концентроване вираження інтересів суспільства, організованого в державу. На мою думку, приватні, індивідуальні й суспільні інтереси не можна протиставляти. Держава виступає в цивільному праві також як приватна особа-власник. Якщо держава є носієм суб’єктивного права власності, то в сфері цивільного обігу вона фактично діє як відокремлена або приватна особа. В сфері приватного права державі властиві свої інтереси, окремі від інших категорій осіб.

Досліджуючи вплив норм публічного права на сферу приватного права, слід звернути увагу на функцію охорони і захисту прав та інтересів громадян державою, яка може здійснюватися через регулювання економічних відносин. В цьому контексті найбільш важливими формами впливу є встановлення обмеження цивільних прав, державна реєстрація прав на нерухомість і угод з нею, а також включення імперативних норм, що містять приписи і заборони [3, с. 32-34].

Встановлюючи обмеження, держава реалізує функцію охорони і захисту прав та інтересів третіх осіб. Обмеження є складовим елементом правового режиму власності. Однак як сама можливість обмежень, так і їх характер можуть визначатися законодавцем не довільно та не свавільно. Права суб'єктів можуть бути обмежені законом настільки, наскільки це необхідно з метою захисту основ конституційного ладу, моральності, здоров'я, прав і законних інтересів інших осіб, забезпечення оборони країни і безпеки держави.

Власники мають рівні можливості щодо здійснення та захисту своїх правомочностей. Так, відповідно до ст. 13 Конституції України, «держава забезпечує захист прав усіх суб’єктів права власності і господарювання» [19]. Тобто, виступаючи га- 
рантом реалізації законних прав, держава забезпечує одночасно і виконання громадянами обов'язків, покладених на них державою, а також власними договірними та іншими зобов' язаннями.

Конституція України, Цивільний кодекс України надають всім власникам рівні умови для захисту права власності. Власнику необхідно забезпечити можливість здійснювати свої повноваження в повному обсязі. Власник має право на свій розсуд вчиняти щодо належного йому майна будь-які дії, які не суперечать закону та не порушують права та охоронювані законом інтереси інших осіб. Саме такий висновок вбачається з аналізу ч. 1 ст. 64 Конституції України, в якій зазначено, що конституційні права не можуть бути обмежені, крім випадків, передбачених Конституцією України. Це загальне правило стосується і права приватної власності як конституційного права [30].

В ч. 2 ст. 64 вказано права і свободи, які не можуть бути обмежені в умовах воєнного та надзвичайного стану. Оскільки серед перерахованих в цій нормі права власності немає, то можна зробити припущення про принципову можливість обмеження права власності. Відповідно до Закону України «Про правовий режим надзвичайного стану», на юридичних осіб може бути покладена квартирна, їх ресурси можуть бути мобілізовані та використані для відвернення небезпеки, ліквідації надзвичайної ситуації, їх діяльність може бути орієнтована на виробництво необхідної нової продукції. Може бути тимчасово заборонено будівництво, встановлено карантин [32].

В Законі України «Про правовий режим воєнного стану» передбачено можливість використання потужностей підприємств для потреб оборони, вилучення від всіх власників майна, зокрема транспортних засобів, для потреб оборони. Квартирна повинність може бути застосована і щодо громадян. В разі порушення вимог або невиконання заходів правового режиму воєнного стану може бути вилучено відповідне обладнання [34]. Тобто, кожен із цих різних за змістом заходів, який може бути застосований в умовах воєнного та надзвичайного станів, є обмеженням права власності.

Законодавець зазначає, що перелік підстав обмеження права приватної власності, визначений у цих законах, є вичерпним. На мою думку, важливо дослідити природу юридичної конструкції обмеження права власності та з'ясувати можливість встановлення додаткових обмежень [27].

Щодо природи, сутності та підстав встановлення обмеження та обтяження права власності у цивілістичній літературі триває дискусія. Ця дискусія створила передумови для висновку про те, що звузити межу права власності може не лише закон, а й договір. Межа права власності існує в момент виникнення права, тобто ще до початку його здійснення. Межа права стає одночасно межею його здійснення. Аналіз вітчизняного законодавства дає підставу дійти висновку, що звуження (обмеження) змісту конституційного права власності можливе не лише за умови оголошення надзвичайного та воєнного станів.

В Законі України «Про державну реєстрацію речових прав на нерухоме майно та ïх обмежень» зазначено: «Обмеження речових прав на нерухоме майно (обтяження нерухомого майна) - це обмеження або заборона розпорядження нерухомим майном, 
встановлена відповідно до правочину (договору), закону або актів органів державної влади, місцевого самоврядування, їх посадових осіб, прийнятих у межах повноважень, визначених законом» [33]. Тобто, обмеження стосується розпорядження майном і полягає у звуженні можливості розпоряджатися майном або у повній її забороні.

В Законі України «Про забезпечення вимог кредиторів та реєстрацію обтяжень», який стосується лише рухомого майна, міститься таке правило: «Обтяженням є право обтяжувана на рухоме майно боржника або обмеження права боржника чи обтяжувача на рухоме майно, що виникає на підставі закону, договору, рішення суду чи інших дій фізичних і юридичних осіб, з якими закон пов'язує виникнення прав і обов'язків щодо рухомого майна» [31].

Відповідно до ч. 2 ст. 321 ЦК особа може бути обмежена у здійсненні права власності лише у випадках і в порядку, встановлених законом [20]. В ст. 110 Земельного Кодексу України на використання власником земельної ділянки або її частини може бути встановлено обмеження (обтяження) в обсязі, передбаченому законом або договором [32]. Згідно ч. 2 ст. 111 ЗК обмеження використання земельної ділянки підлягають державній реєстрації [23]. Крім цього, в ч. 3 ст. 1241 ЦК будь-які обмеження та обтяження, встановлені в заповіті для спадкоємця, який має право на обов'язкову частку у спадщині, дійсні лише щодо тієї частини, яка перевищує його обов'язкову частку [28].

Щодо використання земельних ділянок сільськогосподарського призначення у Цивільному кодексі України було визначено поняття «цільового призначення». Цільове призначення в цивілістичній літературі інколи використовують для позначення загальної межі здійснення цивільних прав. Визначення цільового призначення земельної ділянки міститься у ст. 1 Закону України «Про землеустрій» .

Згідно запропонованого законодавцем формулювання цільове призначення використання земельної ділянки за призначенням, визначеним на підставі документації із землеустрою у встановленому законодавством порядку [36]. Поняття «цільове призначення земельної ділянки» нерозривно пов'язане з поняттям «категорія земель».

Так, у ст. 19 Земельного кодексу України передбачено, що землі України за основним цільовим призначенням поділяються на категорії [25]. Отже, категорія це основне цільове призначення кожної земельної ділянки. В межах кожної категорії земель виділено окремі види цільового призначення земель [37]. Поділ земель на окремі види цільового призначення земель передбачає встановлення окремих правових режимів. Насамперед це стосується екосистемних функцій, які вони виконують, типів забудови, типів об'єктів, які мають особливу цінність.

Межі здійснення права власності можуть встановлюватися у законі в різні способи [15, с. 20-21]: 1) вказівка на цільове використання майна - житлові будинки, квартири можуть використовуватися лише для постійного проживання; 2) вказівка на способи реалізації права власності; 3) встановлення особливих правил набуття права власності на окремі види майна та законодавче встановлення переліку видів майна, яке не може належати власнику; 4) встановлення особливих правил про форму правочинів, що опосередковують перехід права власності на окремі види майна; 5) встановленням юридичного обов’язку щодо утримання об'єкта права власності. 
Власник зобов’язаний утримувати майно, що йому належить. Окремим способом розпорядження житлом є зміна цільового призначення приміщення. Законодавець встановлює обмеження щодо такого переведення [36]. Нині розпорядження житлом у формі переведення з жилого фонду у нежилий прямо не заборонено законодавством. На мою думку, таке переведення має бути можливе лише з певними застереженнями. Такі застереження мають бути накладені в подальшому використанні переведеного в нежилий фонд житла, і вони мають бути покликані унеможливити порушення житлових прав громадян, які проживають у суміжних або сусідніх жилих приміщеннях.

На цю обставину вказують сучасні дослідники. Вони зазначають, що особа, яка маєправовласностінавідповіднежилеприміщення, маєправовикористовуватийого на власний розсуд. При цьому слід враховувати інтереси інших громадян, які використовують приміщення для проживання, особливо якщо йдеться про приміщення, яке при забудові планувалося використовувати виключно для проживання [13].

В контексті досліджуваної проблематики зауважу, що право власності припиняється в примусовому порядку в разі припинення права власності на майно, яке за законом не може належати цій особі; викупу пам'яток історії та культури; викупу земельної ділянки у зв'язку із суспільною необхідністю; викупу нерухомого майна з метою суспільної необхідності в земельній ділянці, на якій воно розміщене; звернення стягнення на майно за зобов’ язаннями власника; реквізиції; конфіскації[21].

Особливе місце серед підстав припинення права власності посідає знищення майна, оскільки воно може здійснюватися як самим власником, так і іншими особами. В останньому випадку право власності також припиняється незалежно від волі власника, тобто примусово. Крім того, законом можуть встановлюватися й інші підстави примусового припинення права власності. Наприклад, законодавець окремо визначає підстави для примусового припинення прав на земельну ділянку [24]. Головною метою примусового позбавлення власника права на річ є саме припинення його права власності на цю річ, а не його набуття державою чи територіальною громадою у власність. Примусові способи позбавлення права власності характеризуються тими самими ознаками, що й державний чи правовий примус.

Цікавим є той факт, за яким пряме розмежування підстав припинення права власності на добровільні та примусові в законодавстві багатьох держав передбачено та практично здійснюється, на відміну від цивільного законодавства України [26]. Перелік примусових підстав припинення права власності є вичерпним. На мою думку, таке регулювання припинення права власності є логічним і виправданим, оскільки примусовий викуп чи вилучення майна у власника обмежує основоположний принцип непорушності права власності. Для того, щоб уникнути будьяких спроб щодо розширення цього переліку, доцільно в ЦК України закріпити всі підстави примусового припинення права власності, щоб уникнути можливості будь-якого розширеного тлумачення цієї норми.

Дослідження проблем примусового припинення права власності дає підстави для припущення про те, що в цьому процесі особливу роль відіграє експропріація. Експропріація є інститутом публічного, а не приватного права. Представники школи приватного права, досліджуючи експропріацію, зауважують 
про особливості розуміння цієї категорії. Експропріація (примусове вилучення) розуміється як обов'язкове виконання приватними особами обов'язку на користь публічної влади.

Інструмент, за допомогою якого держава виконує свої обов'язки і тим самим легітимізує себе, має декілька розумінь: «право держави на примусове відчуження приватної власності», «експропріація в інтересах суспільної користі», «вилучення». При цьому У. Меттеї зазначає, що право держави на примусове відчуження приватної власності є одночасно і важливим, і небезпечним. «Всі сучасні правові системи в основу механізмів «цивілізованого» втручання держави закладають два критерії: 1) загальнокорисний; 2) необхідність справедливої компенсації» [4, с. 275-278]. Це свого роду гарантії, які надаються суб'єктивному праву власника від посягань з боку держави.

На практиці реалізується підхід, за якого при наявності чітко вираженого публічного інтересу для його задоволення нехтують законністю та балансом приватного і публічного [10, с. 36]. Для визначення критерію суспільної корисності в контексті цього питання необхідно враховувати дві категорії (враховуючи етимологію слова): «суспільство» і «корисність». «Суспільство» розуміється як та чи інша сукупність, група людей [1, с. 34], «корисність»- як придатність для служіння певній меті [18]. Оскільки йдеться про суспільні потреби, загальну корисність слід розуміти як придатність для задоволення інтересів всього суспільства або його частини (в тому числі і держави).

Постає питання, чи відповідає правове регулювання відносин власності в Україні європейським стандартам? Для аргументованої відповіді на це питання необхідно проаналізувати положення Цивільного Кодексу України та Європейської конвенції про захист прав людини та основоположних свобод [2]. У Конвенції зазначено, що ніхто не може бути позбавлений своєї власності інакше як в інтересах суспільства і на умовах, передбачених законом і загальними принципами міжнародного права [30]. Проте попередні положення в жодному разі не обмежують право держави вводити в дію такі закони, які вона вважає за необхідне, щоб здійснювати контроль за користуванням майном відповідно до загальних інтересів або для забезпечення сплати податків чи інших зборів або штрафів.

Як зазначає О. Дзера, дія принципу непорушності права власності не є абсолютною [2]. С. Погрібний вказує, що міжнародно-правові документи визначають дві підстави обмеження (позбавлення проти волі власника) права власності. Перша з них - формальна. Вона полягає в тому, що будь-який випадок позбавлення права власності проти волі його суб'єкта має бути передбачений законом. Друга підстава - матеріальна. В законі може бути передбачена тільки така підстава позбавлення власника його права, яка зумовлена домінуючими інтересами суспільства [7, с. 234].

Примусове відчуження об’єктів права власності може бути застосоване лише як виняток з мотивів суспільної необхідності на підставі і в порядку, встановлених законом, та за умови попереднього та повного відшкодування їх вартості, крім випадків, встановлених ч. 2 ст. 353 Цивільного Кодексу України [35]. Отже, положення ЦК України повністю відповідають європейським стандартам. 
Всі перелічені в законі підстави мають подвійну природу. У зазначених випадках власник втрачає права володіння, користування та розпорядження майном; в той же час право власності на майно виникає в іншої особи - суб'єкта публічного права, який здійснює владні функції. Примусове відібрання у власника його майна через ініціативу державної влади є таким способом припинення права власності, при якому з точки зору цивільного права основне значення має не набуття майна державою, а втрата його приватною особою [5, с. 430].

Потрібно пам'ятати, що згідно принципу неприпустимості позбавлення права власності власникові належить право володіння, користування та розпорядження майном відповідно до закону за своєю волею й незалежно від волі інших осіб; ніхто не може бути протиправно позбавлений цього права чи обмежений у його здійсненні; всі заборони й обмеження права власності застосовуються лише як заходи захисту публічних інтересів. Цей принцип робить випадки вилучення майна у власника необхідним і чітко обмеженим винятком із загального правила. Дія цього принципу виключає можливості необгрунтованого присвоєння чужого майна і нових «переділів власності» .

Висновки. Дослідження актуальних проблем розвитку відносин власності та формулювання конкретних пропозицій щодо вдосконалення законодавства з метою вирішення цих проблем передбачають аналіз вітчизняного законодавства та практики його застосування, а також зарубіжного досвіду.

Головною тенденцією трансформації власності та права власності є подолання домінування приватної власності як однієї з класичних форм власності та її становлення як рівноцінної з іншими формами відносин відчуження-присвоєння матеріальних благ. Відбувається перехід до змішаної структури відносин власності, яка передбачає виникнення, здійснення та реалізацію складних відносин володіння, користування, розпорядження відповідно до існуючих економічних, суспільних і геополітичних реалій. Значних змін зазнає зміна у сприйнятті природи та розумінні сутності самих відносин присвоєння.

Ця тенденція передбачає розвиток різних форм власності на основі їх диференціації та інтеграції, появу нових об'єктів і множинності суб'єктів присвоєння, становлення на цій основі економічної системи якісно нового типу. Одним із пріоритетних завдань у сфері правового регулювання речових правовідносин є пошуки та встановлення балансу між публічною та приватною власністю.

\section{Jimepamypa}

1. Данильян О.Г., Дзьобань О.П., Жданенко С.Б. та ін.; за ред. О.Г. Данильяна. Х. : Право, 2014. $392 \mathrm{c}$.

2. Дзера А.В. Институт права собственности по новому гражданскому законодательству Украины и европейские стандарты по охране права собственности // Альманах цивилистики : Сб. ст. Вып. 1 / Под ред. Р.А. Майданика. К. : Всеукраинская ассоциация издателей «Правова єдність», 2008. C. $190-221$.

3. Манукян А.А. Ограничения права собственности нормами публичного и частного права // Право и экономика. 1997. № 17-18. С. 32-34.

4. Маттеи У., Суханов Е.А. Основные положения права собственности. М. : Юристъ, 1999. 384 с.

5. Мейер Д.И. Русское гражданское право (в 2 ч.). Часть $1 / /$ По исправленному и дополненному 8-му изд., 1902. Изд. 3-е, испр. М. : «Статут», 2003. (Классика российской цивилистики.) 
6. Мічурін Є.О. Обмеження майнових прав фізичних осіб (теоретико-правовий аспект). Монографія. Х. : Юрсвіт, НДІ приватного права і підприємництва АПрН України, 2008. 482 с.

7. Погрібний С.О. Механізм та принципи регулювання договірних відносин у цивільному праві України. К. : Правова єдність, 2009. С. 234.

8. Покровский И.А. Основные проблемы гражданского права. М. : Статут, 1998. С. 11-14.

9. Право власності в Україні : навч. посіб. / О.В. Дзера, Н.С. Кузнецова, О.А. Підопригора та ін. За заг. ред. О.В. Дзери, Н.С. Кузнєцової. К. : Юрінком Інтер, 2000. 816 с.

10. Скловский К.И. Вопрос о пределах вмешательства государства в частную собственность в судебной практике // Хозяйство и право. 2002. № 6. С. 34-41.

11. Суханов Е.А. Проблемы правового регулирования отношений публичной собственности и новый Гражданский кодекс // Гражданский кодекс России. Проблемы, теория, практика / Отв. ред. А.Л. Маковский. М. : Международный центр финансово-экономического развития, 1998. С. $205-277$.

12. Цивільне право України : підручник в 2-х т. / [Борисова В.І., Баранова Л.М., ЖКилінкова I.В. та ін.]; за заг. ред. В.І. Борисової, І.В. Спасибо-Фатєєвої, В.Л. Яроцького. К. : Юрінком Інтер, 2007. T. 1. 480 c.

13. Цивільний кодекс України: науково-практичний коментар (пояснення, тлумачення, рекомендації з використанням позицій вищих судових інстанцій, Міністерства юстиції, науковців, фахівців). Т. 5. Право власності та інші речові права / За ред. проф. І.В. Спасибо-Фатєєвої. Серія «Коментарі та аналітика». Х. : ФОП Лисяк Л.С., 2011. 624 с.

14. Цивільний кодекс України: науково-практичний коментар із змінами і доповненнями станом на 1 січня 2008 р. / За заг. ред. Є.О. Харитонова, О.І. Харитонової, Н.Ю. Голубєвої. К. : Всеукраїнська асоціація видавців «Правова єдність», 2008. 740 с.

15. Яворська О.С. Договірні зобов'язання про передання майна у власність: цивільно-правові аспекти : монографія / О.С. Яворська. Тернопіль : Підручники і посібники, 2009. 384 с.

16. Яворська О.С. Правове регулювання відносин власності за цивільним законодавством України : навчальний посібник. К. : Атіка, 2008. 256 с.

17. http://dspace.nbuv.gov.ua/bitstream/handle/123456789/14002/08-Goraynov.pdf.

18. http://gkodeksrf.ru/ch-1/rzd-2/gl-15/st-235-gk-rf.

19. https://cyberleninka.ru/article/n/utilitarizm-i-bentama-i-dzh-s-millya-ot-dobrodetelik-ratsionalnosti.

20. https://kodeksy.com.ua/konstitutsiya ukraini/statja-13.htm.

21.https://kodeksy.com.ua/tsivil_nij_kodeks_ukraini/statja-321.htm.

22.https://kodeksy.com.ua/tsivil_nij_kodeks_ukraini/statja-346.htm.

23. https://kodeksy.com.ua/zemel_nij_kodeks_ukraini/statja-110.htm.

24. https://kodeksy.com.ua/zemel_nij_kodeks_ukraini/statja-111.htm.

25.https://kodeksy.com.ua/zemel_nij_kodeks_ukraini/statja-140.htm.

26.https://kodeksy.com.ua/zemel_nij_kodeks_ukraini/statja-19.htm.

27.https://kodeksy.com.ua/zhitlovij_kodeks_ukrains_koi_rsr/statja-8.htm.

28. https://pidruchniki.com/1090052551452/pravo/obmezhennya_prava_vlasnosti.

29. https://protocol.ua/ua/tsivilniy_kodeks_ukraini_stattya_1241/.

30. https://www.echr.coe.int/Documents/Convention_UKR.p̄df.

31. https://www.president.gov.ua/ua/documents/constitution/konstituciya-ukrayini-rozdil-ii.

32. https://zakon.rada.gov.ua/laws/show/1255-15.

33. https://zakon.rada.gov.ua/laws/show/1550-14.

34. https://zakon.rada.gov.ua/laws/show/1952-15.

35. https://zakon.rada.gov.ua/laws/show/389-19.

36. https://zakon.rada.gov.ua/laws/show/435-15.

37. https://zakon.rada.gov.ua/laws/show/858-15.

38. https://zakon.rada.gov.ua/laws/show/z1011-10. 


\begin{abstract}
Анотація
Пацурківський Ю. П. Окремі проблеми розуміння природи відносин власності та права власності. - Стаття.

Право власності, його типи, форми, види, підстави примусового припинення користуються підвищеною увагою дослідників. Власність слід розглядати як цілісну категорію, яка існує як єдність закономірно існуючих і взаємно пов’язаних частин, типів, форм і видів власності.

У науці цивільного права триває дискусія щодо методологічних основ власності і права власності, пов'язана з поверненням у сферу приватного права класичної концепції поділу права на публічне та приватне. $Є$ кілька підходів до визначення критерію поділу права на публічне та приватне. Насамперед це матеріальні і формальні теорії. Серед них окреме місце займає теорія інтересу. Ї̈̈ зміст визначається твердженням, що право, яке охороняє інтереси держави, - це публічне право, а право, яке охороняє інтереси приватної особи, - приватне.

Для розмежування публічного і приватного права критерію інтересу не досить. Власність за своїм внутрішнім змістом $є$ необмеженим, повним, вільним пануванням людини над річчю. Межі та обмеження здійснення права власності існували в усіх державах. Власність обмежена інтересами суспільства, потребами взаємодії між окремими членами суспільства та організаціями. Держава уповноважена регламентувати цю взаємодію, об'єктивне право її регулює, може встановлювати межі та покладати на власника обов'язки. Тобто, встановлюючи обмеження, держава реалізує функцію охорони і захисту інтересів третіх осіб. Обмеження є складовим елементом правового режиму власності.

Власники мають рівні можливості щодо здійснення та захисту своїх правомочностей. Природа власності не впливає на цю можливість. Захист законних прав громадян є головним завданням держави, кожна цивілізована держава закріплює за своїми громадянами та юридичними особами та прагне створити умови для їх реалізації. Межі здійснення права власності можуть встановлюватися в законі у різні способи: вказівка на цільове використання майна; вказівка на способи реалізації права власності.

Ключові слова: поділ права на публічне та приватне, публічний інтерес, приватний інтерес, інтереси суспільства, межі та обмеження здійснення права власності, правовий режим власності, обтяження права власності, примусове припинення права власності, знищення майна, вилучення майна для задоволення суспільних потреб.
\end{abstract}

\title{
Summary
}

Patsurkivsky Yu.P. Some problems of understanding the nature of property relations and property rights. - Article.

The right of property, its types, forms, types, grounds for compulsory termination of use increased attention of researchers. Property should be viewed as a holistic category, which exists as a unity naturally existing, and mutually related parts, types, forms and types of ownership. In civil law there is still debate concerning the methodological foundations of ownership and property rights associated with returning to private law the classical concept of division of law into public and private.

There are several approaches to the definition of criteria for the division of law into public and private. First of all it's material and formal theory. Among them a special place is the theory of interest. The right which protects the interests of private persons - private.

To distinguish public and private law criterion of interest is not enough. Property in its inner content, unlimited, full, free, man's dominion over a thing. Limits to the exercise of the right of ownership existed in all States. Property is limited to the interest, needs interaction between individual members of society and organizations. The state is entitled to regulate this interaction, objective law regulates her to set boundaries and to assign to the owner responsibilities. That is, when imposing restrictions, the state implements the function of protection of interests of third parties.

Limits are an integral element of the legal regime of ownership. Owners have equal opportunities regarding the exercise and protection of their legal rights. The nature of ownership does not affect this possibility. Protection of the legitimate rights of citizens is the main task of the state, every civilized nation gives its citizens and legal persons and seeks to create the conditions for their implementation. Limits on the exercise of ownership rights can be established in the law in different ways. Such methods include: an indication of the intended use of the property; indication of the means of exercising the right of ownership.

Key words: public law, private law, public interest, private interest, public interest, boundaries and restrictions on the exercise of property rights, legal regime of ownership, encumbrance of property rights, compulsory termination of property rights, destruction of property, seizure of property to satisfy public needs. 